\title{
Age and Growth of the Finescale Triggerfish, Balistes polylepis (Teleostei: Balistidae), on the Coast of Mazatlán, Sinaloa, Mexico ${ }^{1}$
}

\author{
Ithandehui Barroso-Soto, ${ }^{2}$ Emerita Castillo-Gallardo ${ }^{2}$ Casimiro Quiñonez-Velázquez, 3,4 \\ and Ramón E. Morán-Angulo ${ }^{2}$
}

\begin{abstract}
To estimate the weight-length relationship, determine age, and describe growth of the finescale triggerfish, Balistes polylepis Steindachner, 1876, 552 specimens were measured and weighed, and 318 first dorsal spines were collected from the artisanal catch in Mazatlán, Sinaloa, Mexico, between October 2000 and October 2001. Fish ranged between 16 and $53 \mathrm{~cm}$ in total length (TL), and distribution was biased toward small sizes. Age was assigned according to the number of opaque-hyaline bands in spines, identifying seven age groups (1-7), with age groups 2,3 , and 4 jointly representing over $80 \%$ of the collection. The von Bertalanffy model was adequately fitted to the age-TL data and accounted for $91 \%$ of the variation in TL. Parameters were estimated as $\mathrm{TL}_{\infty}=55.8 \mathrm{~cm} ; \mathrm{K}=0.17 \mathrm{yr}^{-1}$, and $\mathrm{t}_{0}=-1.7 \mathrm{yr}$. The total weight $(\mathrm{TW})$ of the finescale triggerfish ranged between 75 and 2,200 g, and the TW-TL relationship showed a negative allometric growth $(b=2.7)$. These results are the first reported for age and growth of this species.
\end{abstract}

The finescale triggerfish, Balistes polylepis Steindachner, 1876 (Balistidae) is distributed across the eastern Pacific Ocean from San Francisco $\left(37^{\circ} 47^{\prime} \mathrm{N}\right)$, California, to San Antonio (33 $35^{\prime} \mathrm{S}$ ), Chile (Brito 2003), including the Gulf of California, Hawai'i, and the Galápagos Islands (Berry and Baldwin 1966). This species is the most abundant of the genus and lives in rocky habitats. Reproduction occurs during July and August, when eggs are laid in nests and tended by females (De la Cruz Agüero et al. 1997). The finescale triggerfish is caught by artisanal fish-

\footnotetext{
${ }^{1}$ Manuscript accepted 2 March 2006.

${ }^{2}$ Facultad de Ciencias del Mar, Universidad Autónoma de Sinaloa. Paseo Claussen s/n, Mazatlán, Sinaloa, Mexico.

${ }^{3}$ Centro Interdisciplinario de Ciencias MarinasInstituto Politécnico Nacional, Apartado Postal 592, Avenida Instituto Politécnico Nacional s/n, Col. Playa Palo de Santa Rita. La Paz, Baja California Sur, C.P. 23096.

${ }^{4}$ Corresponding author (e-mail: cquinone@ipn.mx).
}

Pacific Science (2007), vol. 61, no. 1:121-127

(C) 2007 by University of Hawai'i Press

All rights reserved eries, which use small motorboats and a variety of fishing gear, including nets and lines. These fisheries exploit a great variety of species, and no systematic follow-up of catch records is made by federal fisheries agencies. In Mexico's Statistics Yearbook for Fisheries, the catch of the finescale triggerfish is included under "other species." For the Mexican Pacific coast states, the group named "other species" accounted for $13 \%$ of the arrival artisanal catch between 2000 and 2003 (AEP 2000-2003). Saucedo and Ramírez (1994) pointed out that the finescale triggerfish is captured all year round, peaking in the summer and representing 2\% of the artisanal catch in southern Sinaloa during 1987-1988. This catch pattern matches the one reported by Ramírez (1997) for Bahía de La Paz, Baja California Sur, during 1987-1993.

In general, much remains unknown about the biology of species within the Balistidae (Abitía-Cárdenas et al. 1990, García et al. 1998, Letourneur et al. 1998), and reports about age and growth are scarce (Manooch and Drennon 1987). For Balistes polylepis, just one report is available for Mexico's northwestern region, and it focuses on the gut content of fish collected in Bahía Concepción, 
Baja California Sur (Abitía-Cárdenas et al. 1990).

In this work our aim was to determine the age and describe individual growth and the length-weight relationship of the finescale triggerfish, Balistes polylepis, caught along the coast at Mazatlán (23 $\left.12^{\prime} \mathrm{N}, 106^{\circ} 25^{\prime} \mathrm{W}\right)$, Sinaloa, Mexico.

\section{MATERIALS AND METHODS}

Specimens were sampled on a weekly basis from artisanal fisheries at Playa Norte, Mazatlán, Sinaloa (Figure 1), during the period from October 2000 to October 2001. The fishing area extends from Isla Pájaros $\left(23^{\circ}\right.$ $\left.15^{\prime} \mathrm{N}, 106^{\circ} 28^{\prime} \mathrm{W}\right)$ to Cerro del Crestón $\left(23^{\circ} 10^{\prime} \mathrm{N}, 106^{\circ} 25^{\prime} \mathrm{W}\right)$. Sampling consisted of measuring fork length (FL) and total length (TL) in centimeters and measuring total weight in grams for all finescale triggerfish specimens caught from up to five fishing boats chosen at random. Size structure was determined by grouping TL into $2-\mathrm{cm}$ intervals, and the first dorsal spine was collected

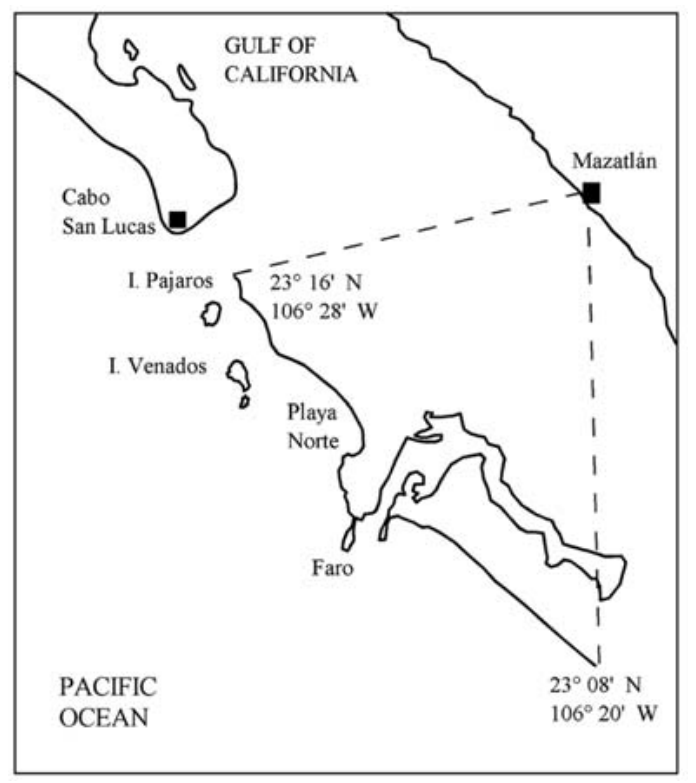

Figure 1. Study area, including an enlargement of the fishing area. Note the references (I. Pájaros and Faro) delimiting the fishing area of the artisanal catch that discharges in Playa Norte. from up to three specimens per size class to determine age.

For age determinations, two cross sections (cuts) were obtained per spine following the methodology of Prince et al. (1984). To ensure consistent location of the cuts, the widest portion of the condyl base was measured and one-fourth of this distance was marked on the spine shank above the condyl base. These sections (0.5-mm-thick slices) were immersed in isopropyl alcohol for $24 \mathrm{hr}$ to remove skin or fat residues and were then mounted on slides using synthetic resin (Alvarado-Castillo and Félix-Uraga 1995).

The spine sections were examined by three readers independently using a stereomicroscope with transmitted light. Under these conditions, sections showed opaque and hyaline zones (Figure 2); the type of zone at the margin of the section (opaque or hyaline) was also recorded. A growth mark consisted of an opaque zone and an adjoining hyaline zone. When counts of these marks by the three readers failed to match, the section was read again by the three readers until agreement was reached.

An image of each section was obtained using an image analysis system, and the section's radius and diameter were recorded using the SigmaScan Pro program (ver. 4.0, 1987-1996, Jandel Scientific).

To validate the use of the spine for determining age and describing the somatic growth of the finescale triggerfish, the relationship between spine diameter and length of fish (TL) was assessed through a linear regression. The deposition time of growth marks was established analyzing the monthly percentage of opaque-margin spines.

Age-TL data were used to calculate the von Bertalanffy equation parameters: $\mathrm{TL}_{t}=\mathrm{TL}_{\infty}\left[1-\mathrm{e}^{-K\left(t-t_{0}\right)}\right]$, where $\mathrm{TL}_{t}$ is total length at age $t, \mathrm{TL}_{\infty}$ is the asymptotic total length, $K$ is the growth constant, $t$ is age in years, and $t_{0}$ is the theoretical age when length is zero. Because of the great variation in length within an age group, the overlap in lengths of adjacent age groups, and the trend toward increasing mean size with older age groups, $\mathrm{TL}_{\infty}$ was estimated using the relationship proposed by Pauly and Munro 


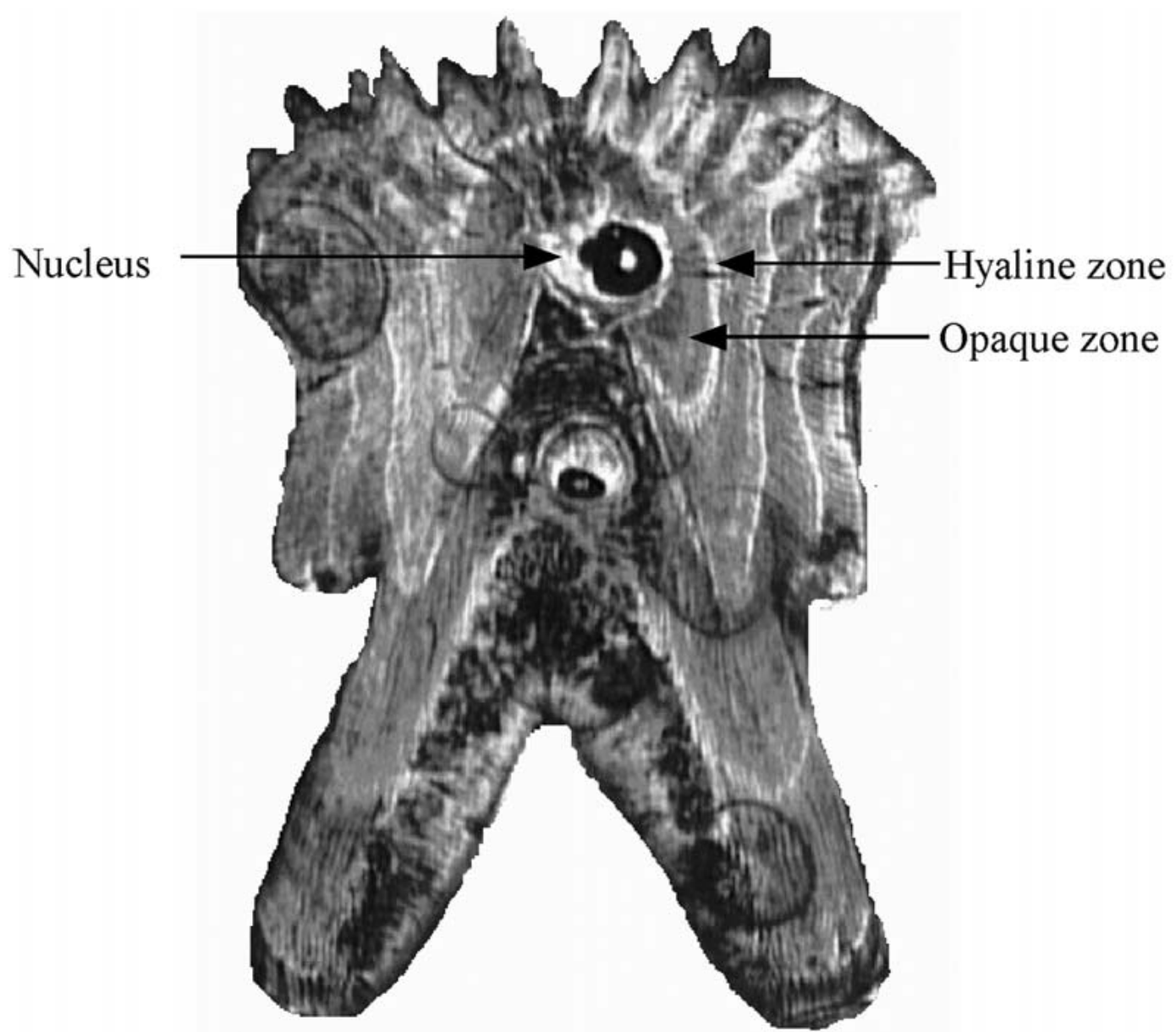

Figure 2. Image of a cross section of a dorsal spine of the finescale triggerfish showing growth zones (hyaline and opaque) and four growth marks.

(1984) $\left[\mathrm{TL}_{\infty}=\right.$ maximum observed total length/0.95].

To examine the catch age structure of $B$. polylepis, an age-TL key was constructed for each month, thus assigning the ages of all individuals for which the spine was not extracted.

The relationship between length and weight was described through the equation $\mathrm{TW}=a^{*} \mathrm{TL}^{b}$, where TW is total weight in grams and TL is total length in centimeters. Coefficients $a$ and $b$ of the equation were estimated using the least squares method, after transforming length and weight data to base10 logarithms.

RESULTS

During the study period, 552 specimens of B. polylepis were measured and weighed, and the dorsal spine was removed from 318 fish (subsample) (Table 1). In many months, this subsample was a large fraction of the total sample; in three months it exceeded $80 \%$, and averaged $58 \%$ overall. However, during five months the numbers of samples were very small or absent due to the lack of availability of fish.

When the size structure of $B$. polylepis was analyzed, a great variation was detected in fork length, which did not correspond to the 
TABLE 1

Monthly Sample Size ( $n$ ) of the Finescale Triggerfish from the Artisanal Catch in Mazatlán, Sinaloa, during October 2000 to October 2001; Percentage of the Sample Used for Dorsal Spine Age Analysis; and Minimum, Maximum, and Mean Total Fish Length (TL)

\begin{tabular}{lrcccc}
\hline \hline Month/yr & $n$ & $\%$ & Minimum & Maximum & Mean \\
\hline October 2000 & 54 & 13 & 20.2 & 42.6 & 29.7 \\
November 2000 & 82 & 18 & 16 & 41.4 & 27.8 \\
December 2000 & 1 & - & 53 & 53 & 33 \\
January 2001 & 2 & - & 23.5 & - & -28 \\
February 2001 & - & - & 28 & 40 & 28 \\
March 2001 & 1 & - & 26.6 & 50.5 & 32.5 \\
April 2001 & 32 & 44 & 19.8 & 46.7 & 32.4 \\
May 2001 & 125 & 70 & 16 & 42.5 & 32.6 \\
June 2001 & 72 & 85 & 24.5 & 38.5 & 25.3 \\
July 2001 & 60 & 37 & 19.2 & 41.5 & 27.5 \\
August 2001 & 43 & 86 & 16.8 & 44.1 & 41.6 \\
September 2001 & 77 & 91 & 39.4 & & \\
October 2001 & 3 & 67 & & & \\
\hline
\end{tabular}

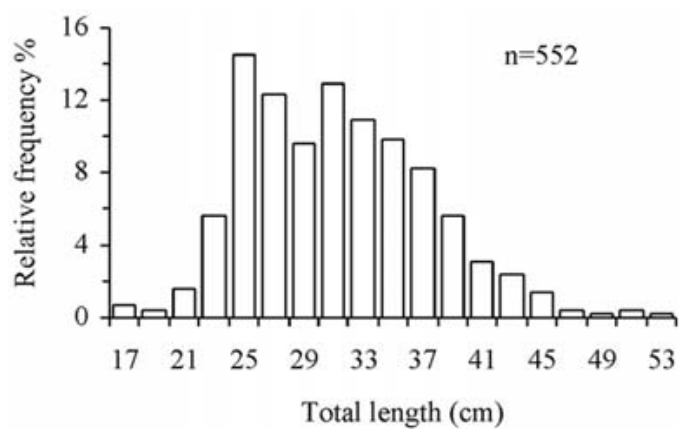

Figure 3. Total length-frequency distribution for the finescale triggerfish caught in Mazatlán, Sinaloa, during October 2000 to October 2001.

variation in total length. Given this inconsistency in the fork length records and because of the impossibility of correcting this sampling problem, it was decided to use only total length in the data analyses. Fish ranged from 16 to $53 \mathrm{~cm}$ in TL (Figure 3), with the mode at $25 \mathrm{~cm} \mathrm{TL}$ and a mean TL of $31 \mathrm{~cm}$; size was not normally distributed (Shapiro-Wilk $W$ test, $P<.001$ ), showing a bias toward small TL. Over $85 \%$ of all specimens measured were between 24 and $38 \mathrm{~cm}$ TL. Table 1 shows the minimum, maximum, and mean TL for each monthly size distribution.

Significant relationships $(P<.01)$ were

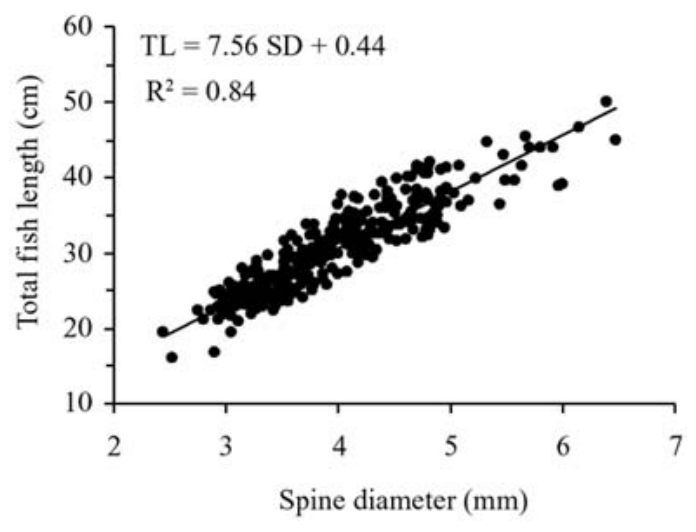

FIgURE 4. Relationship between spine diameter (SD) $(\mathrm{mm})$ and total fish length (TL) $(\mathrm{cm})$ for the finescale triggerfish caught in Mazatlán, Sinaloa. The best-fit regression line and its equation are shown.

found for spine diameter (SD) and spine radius (SR) with total length (TL), but SD showed a higher $\mathrm{R}^{2}$ than SR $(0.84$ and 0.74 , respectively). Figure 4 shows the dispersion for SD and TL around the best-fitted regression line, indicating the proportional relationship in the growth of the two variables, which supports the use of the spine for describing somatic growth in B. polylepis.

The trend in the monthly percentage of opaque-margin spines suggests an annual pat- 


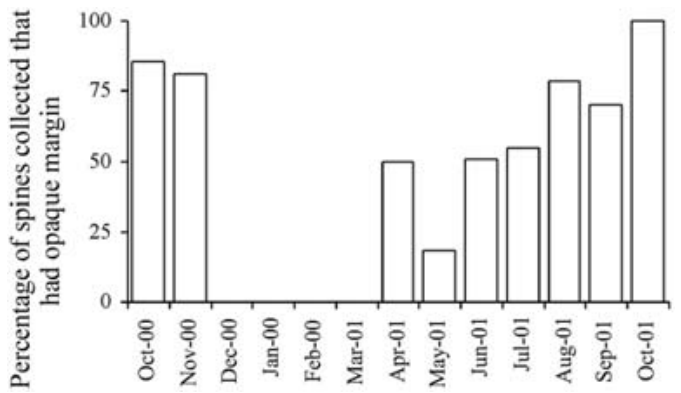

Figure 5. Monthly percentage of opaque-margin spines of the finescale triggerfish caught in Mazatlán, Sinaloa, during October 2000 to October 2001.

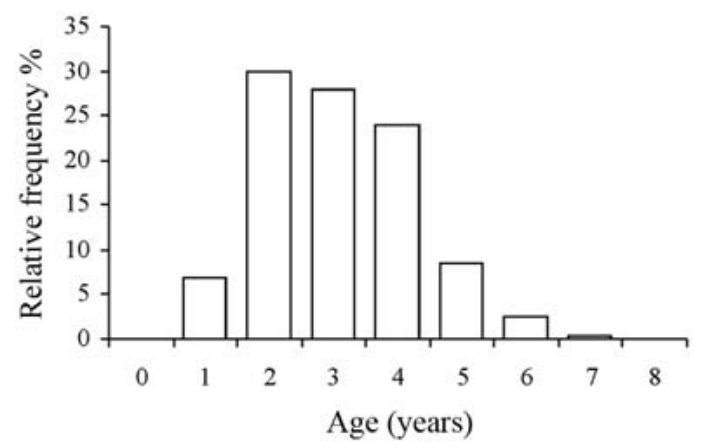

Figure 6. Age-frequency distribution for the finescale triggerfish caught in Mazatlán, Sinaloa, during October 2000 to October 2001, based on monthly age-TL data.

tern (Figure 5), with the opaque zone probably being deposited during the fall-winter and the hyaline zone during the springsummer. It was not possible to define the end and beginning of the formation of each growth form because of the lack of samples from December to March. Nevertheless, it seems plausible that the temporal cycle of formation of a single growth mark (one opaque plus one hyaline zone) would be during $1 \mathrm{yr}$, and consequently that age of finescale triggerfish specimens can be estimated in years corresponding to the number of growth marks in the spine.

Based on these criteria, up to seven age groups were defined, from 1 to $7 \mathrm{yr}$, and the age-frequency distribution shows that the dominant age groups were 2,3 , and $4 \mathrm{yr}$, re-

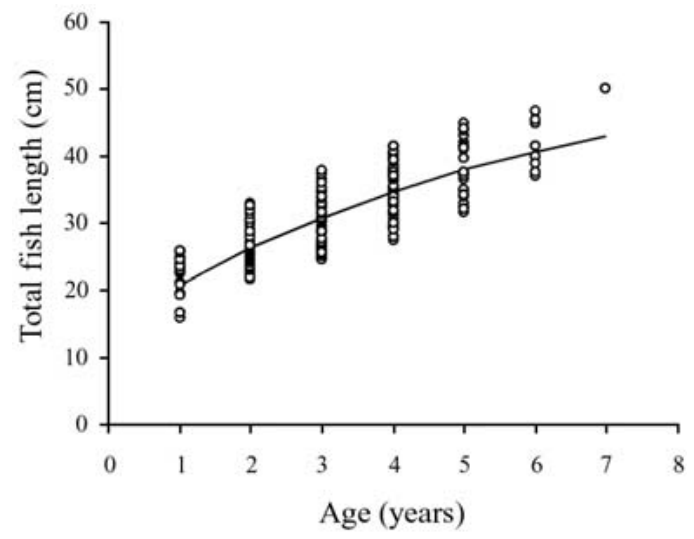

FIgURE 7. Relationship between age and total length for the finescale triggerfish caught in Mazatlán, Sinaloa. The best-fit von Bertalanffy model line is shown.

spectively (Figure 6). These age groups accounted for more than $80 \%$ of all specimens. Two-year-old fishes were dominant from April to July 2001, whereas 3- and 4-yr-old specimens dominated from August to October 2001, and this matches with dominant ages in October and November 2000.

The von Bertalanffy model fits adequately $\left(\mathrm{R}^{2}=0.90\right)$ with the age-TL data (Figure 7$)$. The length data show considerable scatter at all ages, resulting in overlapping between age groups, such that up to three different ages can be assigned to any given size. The asymptotic TL was $55.8 \mathrm{~cm}, K$ was $0.17 \mathrm{yr}^{-1}$, and $t_{0}$ was $-1.7 \mathrm{yr}$. Of course the von Bertalanffy model does not represent growth accurately for the first year or more, based on the limited range of fish sizes in the sample. Much more rapid growth occurs in the first year, and by age 2 , fish reach more than $40 \%$ of the asymptotic length. Afterward the absolute growth rate is much less, on the order of $3 \mathrm{~cm}$ per year.

Total weight of $B$. polylepis specimens ranged from 75 to $2,200 \mathrm{~g}$, and over $70 \%$ of sampled fish weighed between 225 and $675 \mathrm{~g}$. The fit of the TW-TL data to the power function model was highly significant $(P<.001)$ (Figure 8). The value of $b=2.7$ indicates a negative allometric growth $(b \neq 3$, $t$ test, $P<.05$ ). 


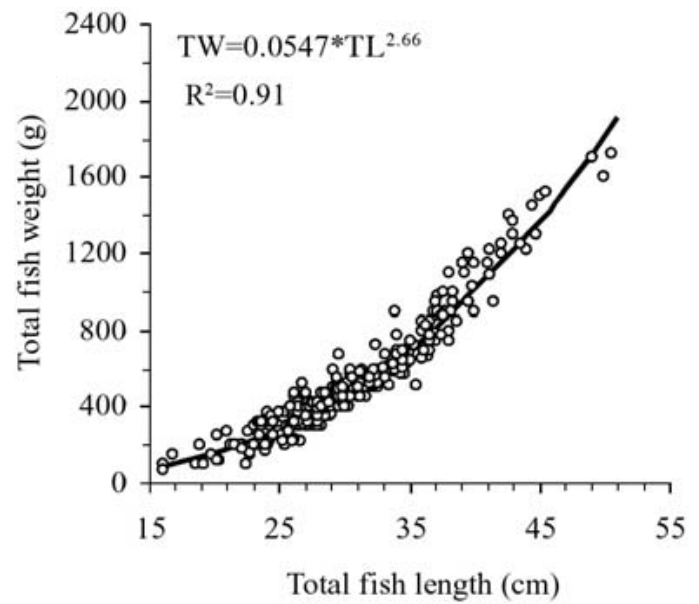

Figure 8. Relationship between total length and total weight for the finescale triggerfish caught in Mazatlán, Sinaloa. The best-fit power function model line is shown.

\section{DISCUSSION}

More than $85 \%$ of specimens measured between 24 and $38 \mathrm{~cm}$ TL, and the full range was $16-53 \mathrm{~cm}$. This indicates that fishermen are catching mainly small fish, based on the maximum length reported for the species, 80 cm TL (De la Cruz Agüero et al. 1997). The lack of samples during December to March is due to the fact that fishermen focus their activity on catching Pacific sierra (Scomberomorus sierra) during that period, because that species has a higher commercial value. Scomberomorus sierra leaves the area in May, and fishermen shift their efforts toward catching other species.

The proportionality in the growth of the first dorsal spine and the fish TL validated the use of the former to estimate the age and to describe the growth of the fish. The age groups found in this study $(1-7 \mathrm{yr})$ are similar to those reported for Balistes vetula (Manooch and Drennon 1987). The trend in the monthly pattern of opaque-margin spines suggested an annual periodicity in the formation of growth marks. This same method, combined with the marginal increment analysis, was used by Manooch and Drennon (1987) for B. vetula in the Virgin Islands and Puerto Rico; those authors concluded that deposition of growth marks was completed in February or March, but our results suggest that this occurs in July and August. The difference in the formation of a growth mark between species probably lies in different reproductive timing, being December-January for B. vetula (Aiken 1983) and July-August for B. polylepis (De la Cruz Agüero et al. 1997).

The asymptotic length $\left(\mathrm{TL}_{\infty}\right)$ was estimated using the equation proposed by Pauly and Munro (1984) due to the great variation in size at each age. This occurs commonly in species from tropical environments and may also be due to the selective pressure of fishing (Pauly and Munro 1984). Studies about age and growth for this fish family are scarce. Ferreira (1985) estimated values of $\mathrm{TL}_{\infty}=54 \mathrm{~cm}$ and $K=0.15 \mathrm{yr}^{-1}$, and Manooch and Drennon (1987) calculated values of $\mathrm{FL}_{\infty}=41 \mathrm{~cm}, K=0.3 \mathrm{yr}^{-1}$, and $t_{0}=-0.6 \mathrm{yr}$ for $B$. vetula. In the investigation reported here the total length of $B$. polylepis was used, and the growth parameters so obtained $\left(\mathrm{TL}_{\infty}=56, K=0.17 \mathrm{yr}^{-1}, t_{0}=-1.7\right.$ yr) are very similar to those estimated by Ferreira (1985).

The estimate of a negative allometric growth $(b=2.7)$ agrees with estimates for species of the same family. García et al. (1998) reported a value of $b=2.81$ for $B$. vetula from the Gulf of Salamanca, Colombia; Letourneur et al. (1998) reported a value of $b=2.5$ for Pseudobalistes fuscus on the coasts of New Caledonia. These values are probably influenced by the laterally compressed shape of these species.

In the study reported here, we provide basic information on the life history of the finescale triggerfish, B. polylepis, an important species exploited by the artisanal fishery. This biological information is useful for developing management plans for the rational exploitation of the resource.

\section{ACKNOWLEDGMENTS}

We acknowledge the collaboration of Felipe N. Melo-Barrera in spine processing, as well as the Fisheries Ecology Laboratory personnel of FACIMAR-UAS, Mazatlán, Sinaloa, during sampling, and the Playa Norte fishermen for their help in conducting the sam- 
pling. C.Q.V. was supported by COFAAEDI-IPN. Thanks to two anonymous reviewers for advice and editorial help.

\section{Literature Cited}

Abitía-Cárdenas, L. A., J. RodríguezRomero, and F. Galván-Magaña. 1990. Observaciones tróficas de tres especies de peces de importancia comercial de Bahía Concepción, B. C. S., México. Invest. Mar. Cent. Interdiscip. Cienc. Mar. 5:55-61.

Aiken, K. A. 1983. The biology, ecology and bionomics of the triggerfishes, Balistidae. Pages 191-205 in T. B. Munro, ed. Caribbean coral reef fishery resources. ICLARM (Int. Cent. Living Aquat. Resour. Manage.) Stud. Rev. 7. 276 p.

Alvarado-Castillo, R. M., and R. Félix-Uraga. 1995. Determinación de la edad de Istiophorus platypterus al sur del Golfo de California. Rev. Biol. Trop. 44:233-239.

AEP. 2000-2003. Anuario estadístico de pesca. Secretaria de Agricultura, Ganaderia, Desarrollo Rural, Pesca y Acuacultura. CONAPESCA, México.

Berry, H. F., and W. J. Baldwin. 1966. Triggerfishes (Balistidae) of the eastern Pacific. Proc. Calif. Acad. Sci. 34:429-474.

Brito, J. L. 2003. Nuevos registros de Balistes polylepis (Balistidae), Sphoeroiides lobatus (Tetraodontidae), Mola mola y $M$. ramsayi (Molidae) en San Antonio, Chile (Pisces, Tetraodontiformes). Invest. Mar. Univ. Catol. Valparaíso 31:77-83.

De la Cruz-Agüero, J., M. ArellanoMartínez, V. M. Cota-Gómez, and G. De la Cruz-Agüero. 1997. Catalogo de los peces marinos de Baja California Sur. CICIMAR-IPN, CoNaBio. 340 p.

Ferreira de Menezes, M. 1985. Biologia pesqueria do cangulo, Balistes vetula Linnaeus: Reproducão e crescimento. Arq. Cienc. Mar. 24:53-59.
García, B. C., J. O. Duarte, N. Sandoval, D. V. Schiller, G. Melo, and P. Navajas. 1998. Length-weight relationships of demersal fishes from the Gulf of Salamanca, Colombia. Naga ICLARM Q. 2:30-32.

Letourneur, Y., M. Kulbicki, and P. Labrosse. 1998. Length-weight relationships of fish from coral reefs and lagoons of New Caledonia, southwestern Pacific Ocean: An update. Naga ICLARM Q. 21:39-46.

Manooch, C. S., III, and C. L. Drennon. 1987. Age and growth of yellowtail snapper and queen triggerfish collected from the U.S. Virgin Islands and Puerto Rico. Fish. Res. 6:53-68.

Pauly, D., and J. L. Munro. 1984. Once more on the comparison of growth in fish and invertebrates. ICLARM (Int. Cent. Living Aquat. Resour. Manage.) Fishbyte 2. 21 p.

Prince, E. D., D. W. Lee, C. A. Wilson, and J. M. Dean. 1984. Progress in estimating age of blue marlin, Makaira nigricans and white marlin, Tetrapturus albidus from the western Atlantic Ocean, Caribbean Sea, and Gulf of México. Int. Comm. Conserv. Atl. Tunas. Coll. Vol. Sci. Pap. 20:435447.

Ramírez-Rodríguez, M. 1997. Producción pesquera en la Bahía de La Paz. B.C.S. Pages 273-304 in J. Urbán-Ramírez and M. Ramírez-Rodríguez, eds.. La Bahía de La Paz: Investigación y conservación. UABCCICIMAR-SCRIPPS. 345 p.

Ramírez-R., M., and C. Rodríguez-M. 1990. Composición especifica de la captura artesanal de peces en la Isla Cerralvo, B. C. S., México. Invest. Mar. Cent. Interdiscip. Cienc. Mar. 5:137-141.

Saucedo-Barrón, C. J., and M. RamírezRodríguez. 1994. Peces de importancia comercial en el sur del estado de Sinaloa, México (pesca artesanal). Invest. Mar. Cent. Interdiscip. Cienc. Mar. 9:51-54. 
